\title{
Implementasi Sensor Suhu dan Kelembaban sebagai Inkubator Penetas Telur Ayam Lokal Berbasis Web Server
}

\author{
Aji Agusdika ${ }^{1}$, Dwi Purwanti ${ }^{2}$, Dhidik Prastiyanto ${ }^{3}$ dan Noor Hudallah ${ }^{4}$ \\ Jurusan Teknik Elektro, Fakultas Teknik, Universitas Negeri Semarang \\ Ajiagusdika@gmail.com1 \\ ithoeq_acad@mail.unnes.ac.id
}

\begin{abstract}
Abstrak - Budidaya penetasan telur bagi peternak ayam masih menggunakan cara konvensional atau masih menggunakan indukan ayam, hal ini dapat diatasi dengan menggunakan mesin penetas telur. Mesin penetas telur merupakan mesin penetasan yang mempunyai prinsip kerja seperti pada induk ayam pada saat mengerami telur. Mesin penetas telur yang ada saat ini dalam memonitoring keadaan inkubator dapat dilakukan hanya dengan mengecek atau melihat alat ukur yang ada pada inkubator. Metode penelitian yang digunakan dalam penelitian ini adalah metode Penelitian Rekayasa (Engineering). Tujuan dari penelitian ini adalah membuat inkubator penetas telur berbasis web server untuk mempermudah monitoring suhu dan kelembaban inkubator secara berkala atau realtime tanpa harus melihat keadaan pada inkubator
\end{abstract}

Kata Kunci- Inkubator, web server, realtime

\begin{abstract}
Egg hatching for chicken breeders is still conventional or reproductively using chicken hatcheries, this can overcome by using egg incubator. Egg incubator is a hatching machine that has a working principle as the mother hen when incubating eggs. Egg incubator that exist today in monitoring the state of the incubator can be made only by check or notice gauge exist in the incubator. The method used in this research is the Engineering Research (Engineering). The purpose of this research is made based egg incubator web serve to facilitate monitoring of temperature and humidity incubator periodically or realtime without seeing condition of the incubator.
\end{abstract}

Keywords: Incubator, web server realtime.

\section{PENDAHULUAN}

Produktivitas ayam lokal yang dipelihara petani di Pulau Jawa, produksi telur masih rendah, berkisar anatara 3060 butir/tahun. Rendahnya produksi disebabkan oleh lamanya periode mengasuh anak dan istirahat bertelur [1]. Salah satu faktor yang mengakibatkan rendahnya produksi telur pada pemeliharaan ayam lokal adalah karena adanya sifat mengeram yang sangat kuat [2]

Pemeliharaan anak secara terpisah dari induk, menghilangkan sifat mengeram dan pemberian ransum sesuai kebutuhan baik jumlah maupun mutunya akan mampu meningkatkan laju pertumbuhan dan menurunkan tingkat kematian anak ayam serta mampu meningkatkan produksi telur ayam lokal [3].

Telur tetas merupakan telur yang didapatkan dari induknya yang dipelihara bersama pejantan dengan perbandingan tertentu. Agar dapat menetas telur sangat tergantung pada keadaan telur tetas dan penanganannya [4]. Budidaya penetasan telur ayam sangat perlu diperhatikan dari segi kestabilan temperatur terutama yang menggunakan inkubator penetas buatan yang masih menerapkan kontrol On/Off di pasaran. Pengontrolan yang masih bersifat On/Off menghasilkan respon waktu relatif lama untuk mencapai keadaan steady state. Disamping itu inkubator penetas telur yang ada dipasaran kurang cocok digunakan pada temperatur lingkungan yang gampang berubah-ubah karena dapat mempengaruhi kestabilan temperatur plant [5]. Mesin tetas merupakan mesin penetasan yang mempunyai prinsip kerja seperti pada induk ayam pada saat mengerami telur. Pada alat penetasan semua faktor-faktor tersebut dapat diatur dengan baik sesuai dengan kondisi yang diinginkan dan sesuai dengan kondisi proses biologi penetasan [6]. Dalam proses penetasan dengan menggunakan mesin tetas memiliki kelebihan di banding dengan penetasan secara alami, yaitu : dapat dilakukan sewaktu-waktu, dapat dilakukan dengan jumlah telur yang banyak, menghasilkan anak dalam jumlah banyak dalam waktu bersamaan, dapat dilakukan pengawasan dan seleksi pada telur [7]. Alat pemanas dihidupkan dan diatur jarak penyetelan antara temperatur $99-102^{\circ} \mathrm{F}$ atau $37-39{ }^{\circ} \mathrm{C}$. Setelah temperatur yang diinginkan tercapai (temperatur konstan). Diatur kelembabannya antara 55-60\%. Pengaturan dilakukan dengan menambah atau mengurangi air dalam bak. Untuk lebih mudahnya biasanya bak diisi air 2/3 bagian dan dibiarkan sampai kelembaban konstan [8].

Pembibitan ayam atau menetaskan telur ayam dengan menggunakan mesin dibutuhkan suhu yang ideal sehingga telur yang baik bisa menetas. Dalam rancangan mesin penetas telur, pemanas yang terlalu lama mati, akan mengakibatkan sumber panas yang dibutuhkan tidak mencukupi, ini akan berdampak benih ayam dalam telur akan mati. Mengatasi 
persoalan tersebut, diperlukan teknologi yang dapat menggantikan sistem konvensional dengan sistem penetasan telur secara otomatis, sehingga dalam proses penetasan telur menjadi lebih mudah, ekonomis dan praktis [9]. Sistem inkubator penetasan telur yang tadinya masih konversional atau menggunakan indukan ayam yang digunakan untuk penetasan telur akan digantikan dengan sistem inkubator penetas telur non konvensional atau berbasis web server sebagai pendukungnya. Modul ESP8266 merupakan board yang memiliki fungsi sebagai penyedia konektivitas untuk arduino sehingga dapat terhubung dengan jaringan wifi dan membuat koneksi TCP/IP melalui UART interface. Sensor jaringan tanpa kabel diimplementasikan dengan menginstal sebuah sensor dengan jaringan yang lebih kecil yang terhubung dengan sebuah perangkat untuk mendapatkan sebuah informasi yang kita butuhkan setiap waktu [10]. Berdasarkan latar belakang tersebut maka penelitian ini akan mendalami tentang perancangan inkubator penetas telur berbasis web server sebagai manajerial inkubator penetas telur. Dalam pembuatan alat ini peneliti menggunakan sensor suhu DHT 22 yang dikoneksi dengan Arduino dan ESP8266 yang dihubungkan dengan web server, yang dimana akan dilakukan system penetasan dengan metode tertutup.

\section{METODE}

Metode penelitian yang digunakan dalam penelitian ini adalah metode Penelitian Rekayasa (Engineering) Pelaksanaan penelitian ini dilakukan pada bulan Februari 2019 sampai Maret 2019. dilakukan

Gambar 1 menunjukkan desain penelitian yang

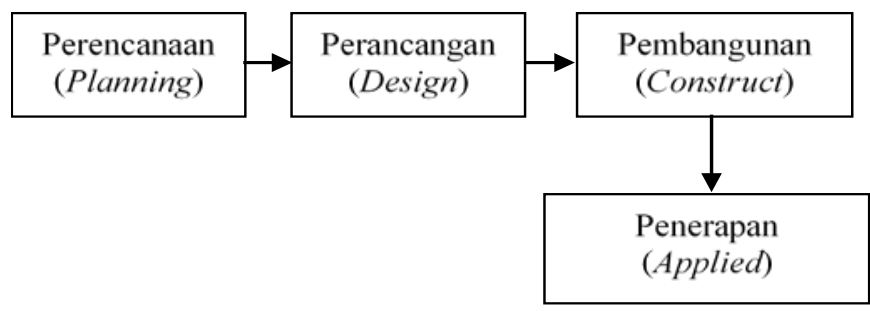

Gambar 1. Desain Penelitian

\section{A. Perancangan (Design)}

Pada tahap perencanaan (Design) merupakan suatu upaya inovasi atau penciptaan suatu metode, formula, model atau prototype berdasarkan kebutuhan calon pengguna yg memerlukannya dalam pemecahan/pengatasan masalah. Pembuatan Inkubator Penetas Telur terbuat dari papan triplek yang dibentuk persegi dengan ukuran $65 \times 55 \times 45 \mathrm{~cm}^{3}$.

Inkubator penetas telur ini di rancang dapat menampung telur sebanyak 40 butir. Lampu pijar digunakan sebagai pemanas suhu ruangan yang di fungsikan untuk penetasan telur. Berikut pada Gambar 2 Desain Perencanaan Alat Inkubator Telur dan Gambar 3 Blok Diagram Sistem.

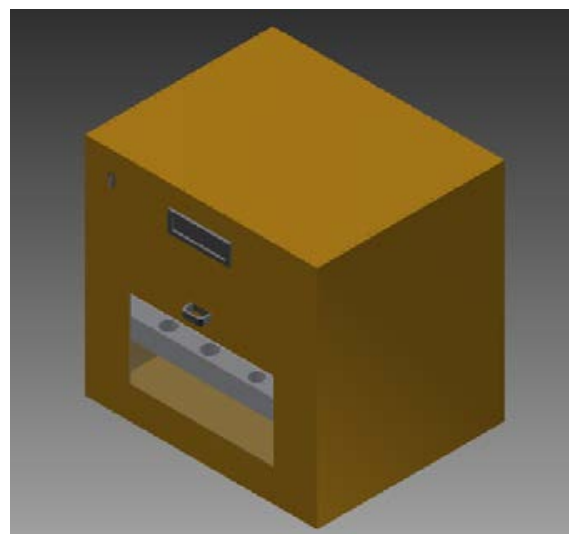

Gambar 2. Desain Perencanaan Alat Inkubator Telur

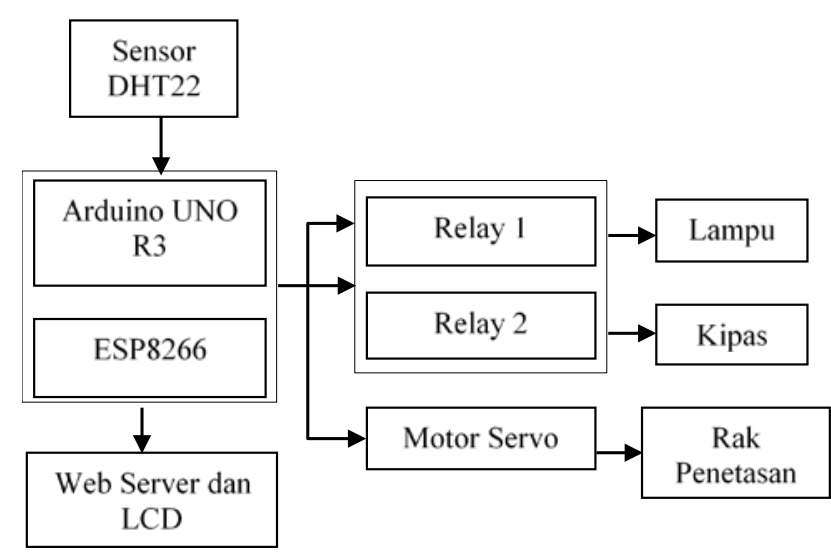

Gambar 3. Blok Diagram Sistem

Gambar 3 merupakan gambaran rancangan sistem yang akan digunakan dimana sensor DHT22 digunakan sebagai pembaca kondisi pada inkubator telur. DHT22 mengirimkan data yang sudah terbaca ke arduino dan arduino mengirmkan data tersebut ke ESP8266 untuk ditampilkan pada Web Server. Arduino akan mengirimkan data suhu dan kelembaban yang telah dibaca dan ditampilkan pada LCD dan Web Server. Pada Web Server data terbaru akan diload pada tabel sehingga dapat menampilkan pembacaan suhu dan kelembaban terkini.

\section{B. Pembangunan (Contruct)}

Pembangunan dilakukan dengan melakukan alat uji terlebih dahulu dengan melakukan uji coba terhadap alat tersebut secara manual (menggunakan thermostat) atau menggunakan alat yang sudah dibuat. Selanjutnya dilakukan perencanaan sensor DHT22 yang memiliki rata-rata nilai kesalahan pengukuran suhu dan kelembaban sebesar $\pm 0,5\left({ }^{\circ} \mathrm{C}\right)$ dan $\pm 2 \%$. Setelah itu melakukan perencanaan ESP8266 yang berfungsi penyedia konektivitas untuk arduino sehingga dapat terhubung 
dengan jaringan wifi dan membuat koneksi TCP/IP melaulai UART interface. Berikut tampilan Rangkaian Sensor DHT22 pada Gambar 4 dan Gambar 5 Rangkaian Ethernet.

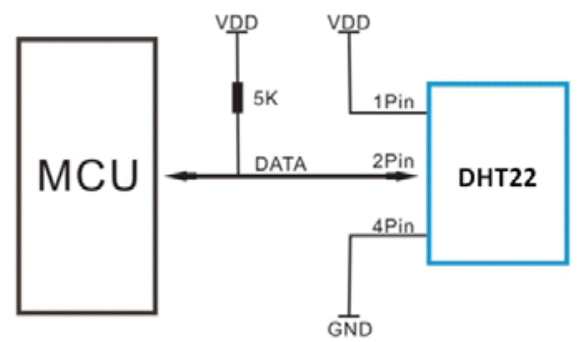

Gambar 4 Rangkaian Sensor DHT22

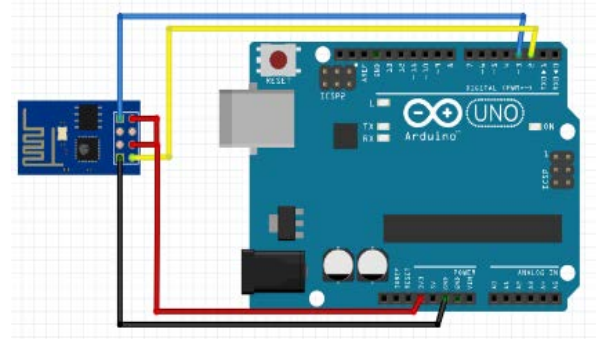

Gambar 5 Rangkaian ESP8266

Tahapan selanjutnya yaitu Perancangan LCD berfungsi untuk menampilkan data hasil pengukuran sensor DHT22. Jenis LCD yang digunakan adalah LCD 16x2 yang telah dipasang dengan module i2c untuk menghemat penggunaan pin pada Arduino. Gambar 6 merupakan rangkaian LCD 16x2 i2c

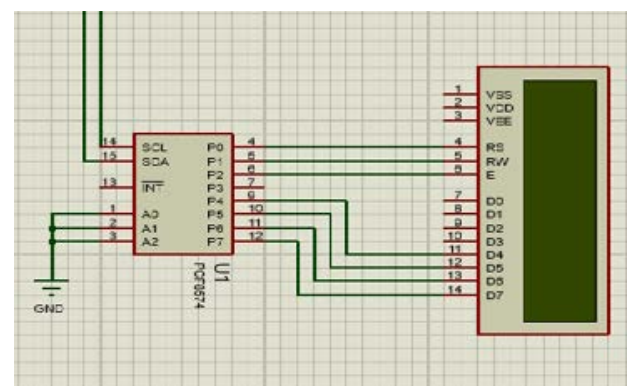

Gambar 6 Rangkaian LCD 16x2 i2c

Tahapan pembangunan yang terakhir adalah Perencanaan Web Server yang menunjukan pengukuran suhu dan kelembaban dengan tampilan tabel. Berikut tampilan web server pada Gambar 7

a. Tampilan web pada laptop

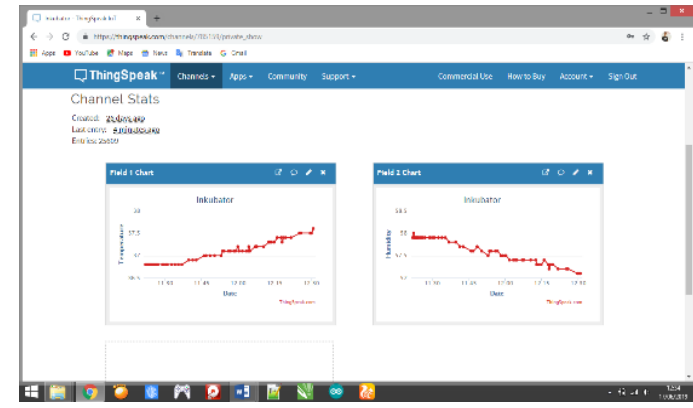

b. Tampilan web pada Smartphone

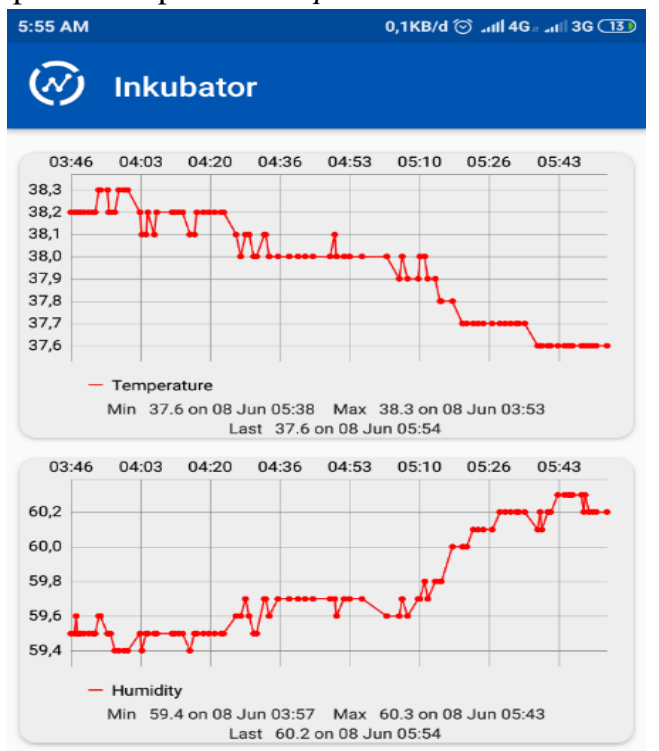

Gambar 7 Tampilan Web Server

\section{Penerapan (Applied)}

Penerapan (Applied) merupakan suatu upaya pengawasan, pengendalian, pemeliharaan, dan evaluasi sesuatau yg telah ditemukan sebelumnya yg relevan dengan kebutuhan dalam pemecahan/pengatasan masalah. Inkubator penetas telur diterapkan dan diuji di daerah Gunungpati, Semarang.

\section{HASIL DAN PEMBAHASAN}

Berdasarkan tujuan dari penelitian ini adalah untuk menghasilkan alat Inkubator penetas telur ayam lokal berbasis arduino dengan menggunakan teknologi web server. Alat ini menggunakan sensor DHT22 yaitu sensor suhu dan sensor kelembaban yang hasilnya dapat dilihat secara realtime 
melalui web server lokal. Alat ini diharapakan dapat memonitoring suhu dan kelembaban pada inkubator menjadi lebih mudah dan akurat. Hasil dari Inkubator penetas telur ayam lokal berbasis arduino dengan menggunakan teknologi web server dapat dilihat pada Gambar 8.

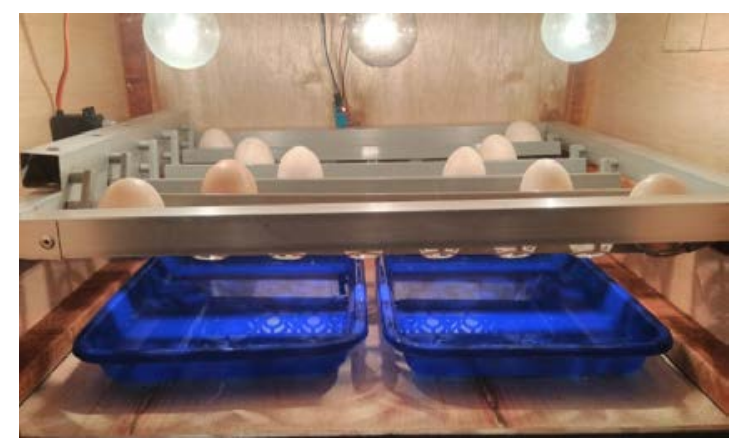

Gambar 8 Inkubator penetas telur ayam lokal berbasis arduino dengan menggunakan teknologi Web server

\section{Analisis Data}

a. Uji coba Sensor Suhu dan Kelembaban DHT 22

Hasil pembacaan sensor terhadap suhu dan kelembaban mempunyai tingkat error yang relatif kecil, dengan hasil pengujian sensor memiliki rata-rata nilai kesalahan pengukuran suhu dan kelembaban sebesar $\pm 0,5\left({ }^{\circ} \mathrm{C}\right)$ dan $\pm 2 \%$. Nilai kesalahan pengukuran ini dimungkinkan karena perbedaan respon sensor DHT 22.

\section{b. Analisis Uji Coba Implementasi Alat}

Analisis pengiriman data pada web server pengujian pengiriman data dilakukan dengan melakukan monitoring. Berdasarkan pengujian yang telah dilakukan, data suhu dan kelembaban berhasil dimonitoring dengan baik, akan tetapi jarak kemampuan perangakat dalam mengirim data sangat terbatas tergantung penggunaan kabel LAN.

Waktu pengiriman data pada web server. Delay yang diimplementasikan pada program mulai dari menyalakan modul hingga pengiriman data pertama adalah 15 detik. Hal ini berarti bahwa apabila sistem berkerja secara normal, maka dibutuhkan waktu 15 detik untuk memulai pengiriman data. Untuk pengirimana data ke dua dan seterusnya menggunakan delay 1 menit sekali. Dalam hal kegagalan konektivitas dan jenis kesalahan lainnya, maka data hanya ditampilkan lewat LCD, kemudian sistem akan mengulangi pengukuran. Berdasarkan pengujian yang telah dilakukan selama 21 hari didapatkan 840 data.

\section{Pembahasan}

\section{- Pembahasan Hasil Uji Alat}

Mengacu pada tujuan penelitian, maka dapat disimpulkan bahwa penelitian yang telah dilakukan telah menghasilkan implementasi sensor suhu dan kelembaban sebagai inkubator penetas telur ayam lokal berbasis web server. Adanya inkubator penetas telur ini dapat menyelesaikan permasalahan dalam hal monitoring yang masih dilakukan dengan cara manual. Hasil uji laboratorium dapat diketahui bahwa alat ini memiliki rata-rata nilai kesalahan pengukuran yang relatif kecil. Hasil uji coba implementasi alat menyatakan bahwa inkubator penetas telur dapat menampilkan hasil pembacaan dari sensor DHT22. Penampilan hasil pengukuran suhu dan kelembaban dapat dilihat pada LCD dan web server.

Bagian pembahasan dalam skripsi hasil analisis peneliti dari data-data yang diperoleh. Dalam bab pembahasan ini keterkaitan dengan rumusan masalah pada BAB I. Penelitian ini dilakukan 4 pengujian yaitu sensor suhu, sensor kelembaban, pengujian web server dan pengujian keseluruhan alat.

Pada pengujian pertama adalah pengujian suhu ruangan inkubator menggunakan sensor DHT22. Pengujian ini dilakukan menggunakan hygrometer digital sebagai parameter untuk kalibrasi. Pengukuran dilakukan selama 1 jam.

Pada pengujian kedua adalah pengujian kelembaban ruangan inkubator menggunakan sensor DHT22. Pengujian ini dilakukan menggunakan hygrometer digital sebagai parameter untuk kalibrasi. Pengukuran dilakukan selama 1 jam.

Pada pengujian ketiga adalah pengujian web server. Pengujian ini dilakukan dengan cara melihat hasil data pada web server dengan menggunakan smartphone dan leptop.

Pada pengujian keempat adalah pengujian keseluruhan alat. Pengujian dimulai pada saat telur dimasukan kedalam inkubator penetas telur, pengujian sensor DHT22 dapat dilihat pada LCD dan web server yang menampilkan hasil pengukuran suhu dan kelembaban ruang inkubator.

Mengacu pada tujuan penelitian, maka dapat disimpulkan bahwa penelitian yang telah dilakukan telah menghasilkan implementasi sensor suhu dan kelembaban sebagai inkubator penetas telur ayam lokal berbasis web server. Adanya inkubator penetas telur ini dapat menyelesaikan permasalahan dalam hal monitoring yang masih dilakukan dengan cara manual. Hasil uji laboratorium dapat diketahui bahwa alat ini memiliki rata-rata nilai kesalahan pengukuran yang relatif kecil. Hasil uji coba implementasi alat menyatakan bahwa inkubator penetas telur dapat menampilkan hasil pembacaan dari sensor DHT22. Penampilan hasil pengukuran suhu dan kelembaban dapat dilihat pada LCD dan web server.

\section{PENUTUP}

\section{Simpulan}

Berdasarkan penelitian yang telah dilakukan dan diimplementasikan, maka dapat disimpulkan bahwa :

1. Implementasi sensor suhu dan kelembaban sebagai inkubator penetas telur berbasis web server dibuat dengan 4 komponen utama yaitu sensor, kontrol, aktuator dan modul wifi. Pada bagian sensor menggunakan DHT22, untuk bagian kontrol 
menggunakan Arduino Uno, untuk aktuator menggunakan kipas dan motor sebagai penggerak rak telur ayam dan untuk modul wifi menggunakan ESP8266 sebagai pengirim data ke web server

2. Sensor yang digunakan adalah sensor DHT22 dimana sensor tersebut dapat mengukur suhu dan kelembaban dengan kesalahan pengukuran suhu dan kelembaban sebesar $\pm 0,5\left({ }^{\circ} \mathrm{C}\right)$ dan $\pm 2 \%$ yang telah dikalibrasi sebelum diterapkan pada inkubator penetas telur.

3. Alat mampu mengatur suhu dan kelembaban inkubator penetas telur secara stabil yaitu pada suhu 37-39 ${ }^{\circ} \mathrm{C}$ dan kelembaban 55-60\% tanpa terpengaruh keadaan luar inkubator.

4. Pada penetasan telur menggunakan inkubator, persentase keberhasilan penetasan telur yaitu $80 \%$ dari 20 telur yang ditetaskan.

\section{Saran}

Beberapa saran yang dapat peneliti sampaikan guna perkembangan dalam penelitian berikutnya adalah sebagai berikut:

1. Dalam penelitian selanjutnya dapat ditambahkan penyemprotan air secara otomatis sebagai pengatur kelembaban inkubator.

2. Menambahkan backup catu daya pada kondisi darurat, karena sisitem yang dirancang saat ini sangat bergantung pada daya listrik.

3. Inkubator Penetas Telur dapat digunakan untuk mengoptimalkan kegiatan penetasan telur agar persentase tingkat keberhasilan penetasan tinggi.

\section{Daftar Pustaka}

[1] Suprijatna, E., "Strategi Pengembangan Ayam Lokal Di Indonesia," Badan Penerbit Universitas Diponegoro. Semarang, 2010.

[2] Suprijatna, E., "Performans Reproduktif Ayam Kampung Pada Pemberian Pakan Campuran Pakan Komersial dan Dedak Halus,” Jurnal Pengembang Peternakan Tropis, 1998.

[3] Suprijatna, E., "Pengaruh Cara Menghilangkan Sifat Mengeram Secara Tradisional Terhadap Performans Ayam Buras Melalui Wadah Koperasi Menyongsong PJPT II,” Bandung: Universitas Negeri Padjadjaran, 1994.

[4] Nuryati, T. N., Sutarto, M. Khamin dan P. S. Hardjosworo., "Sukses Menetaskan Telur," Penebar Swadaya, Jakarta, 1998.

[5] Shaifudin Sofyan, "Sistem Monitoring Pengontrolan Temperatur Pada Inkubator Penetas Telur Berbasis PID,” Jurusan Teknik Elektro, Surabaya: Universitas Negeri Surabaya, 2017.

[6] Nesheim, M. C., R. E. Austic dan L. E. Card, 1979. "Poultry Production," Lea and Febiger, Philadelphia, 1979.
[7] Tri-Yuwanta, "Beberapa Metode Praktis Penetasan Telur,” Fakultas Peternakan UGM, Yogyakarta, 1983.

[8] Jufril, Dhanny., Darwison, B. R., Derisma, "Implementasi Mesin Penetas Telur Ayam Otomatis Menggunakan Metode Fuzzy Logic Control," SEMNASTEK, Jakarta: Universitas Muhamammadiyah Jakarta, 2015.

[9] Josthimani, A. Shirly, E. A., Manoj, G. K., and Karthikeyan, R., "Implementation of Smart Sensor Interface Network for Water Quality Monitoring in Industry using IoT,” Indian Journal of Science and Technology, India: SRM Institut of Science and Teknologi, 2017.

[10] Sugiyono, "Metode Penelitian Pendidikan,” Bandung: Alfabet, 2016. 